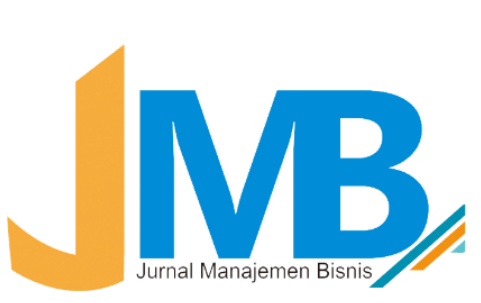

\title{
The Quality of IT Project Management: The Business Process and The Go Project Lean
} Application

\author{
Dewi Nusraningrum ${ }^{1}$, Jaswati ${ }^{2}$, Hakiman Thamrin ${ }^{3}$ \\ Universitas Mercubuana, Jakarta, Indonesia ${ }^{1,2,3}$ \\ Corresponding Author's Email: \\ dewinusraningrum@mercubuana.ac.id
}

Received: 06-01-2020 | Revision: 22-06-2020| Accepted: 01-07-2020

To cite this document:

Dewi Nusraningrum, (2020) "The Quality of IT Project Management: The Business Process and The Applications Go Project Lean", Manajemen Bisnis, Vol. 10, No. 01, pp. 10-23, http://ejournal.umm.ac.id/index.php/imb/article/view/10808

\section{ABSTRACT}

This study is analyzing dominant aspects that affect the quality of software-based project development from the point of view of project management. The purpose of this study is to determine the effect of the business process and Go Project Lean (GPL) application on the quality of information technology project management. The research using a quantitative approach by conducting a survey as the research technique. Questionnaires were using the Likert Scale and developed based on the indicators of variables. The population of this study is the users of the GPL application which are the Sales Division, Project Management Office Division, and Application Development Division of PT. Infomedia Nusantara. Data were analyzed using multiple linear regression method and the hypothesis tested using the T-test. The results showed that the influence of business process and GPL Application is very strong and significant to the quality of IT project management. The implication of these findings caused by one of the dimensions which are no investment feasibility analysis calculation application that effects on-time delivery.

Keywords: IT quality; project management; business process; go project lean; application

\section{INTRODUCTION}

Every company engaged in the business process management services, has a different vision, purpose and mission and need of effective and efficient management, especially in managing projects that the basis of the company's revenue. These projects must be managed properly in order to produce good quality projects. The development of the business process management industry in the Asia Pacific is not as fast as in the United States and Europe, but its growth projected to a significant increase, $61 \%$ in the five-year period from 2011 to 2016 (Noor II, 2015). Conversely, business process management software is still very strange among the Indonesia's software developers. With the market condition of the business process management, many companies have competed in providing the business process management service. However, the majority of business process management vendors in the early stages of development are still dominated by 
software companies in medium scale, so that PT. Infomedia Nusantara potentially grow fast and become a market leader in this industry.

Being a market leader are the goals of PT. Infomedia Nusantara which is depend on the technological advancements. In 2016, PT. Infomedia Nusantara received its fifth award in a row as Frost \& Sullivan's Indonesia Contact Center for Outsourcing Service Provider of the Year. Frost \& Sullivan's Best Practices Awards give awards to regional and global companies, through a thorough analysis of the conditions of industry, markets and companies carried out through in-depth interviews, data analysis and extensive secondary research. This event, which is held every year, is given to companies that are predicted to be able to provide significant growth in each industry category, able to create trends in the market, and have implemented technological innovations that are able to change the future industry map (SWA, 2016).

The problem occurs when the implementation of the application development project, which is one of PT. Infomedia Nusantara products, creates difficulties. The difficulty came from bugs or even sometimes the implementation is not in accordance with the specifications, time, and costs that have been planned and agreed upon previously with the customer. Difficulties in implementation by project manager in IT Project Management because of the application development project is a software which is intangible and more difficult to manage. The previous research results show that there are 3 factors that make managing application development projects more difficult, namely intangibility. Software is not like hardware, so it is more difficult to manage because there are no concrete stages that can be used to measure the level of progress and quality. In addition, software has a complex character and a tendency to constantly change, it also contributes to the difficulties of project management (Samudra, 2006).

Further explained, the quality requirements are also important things that must be considered in maintaining and increasing the continuity and success of an application or software development organization, is management that is effective in managing resources and developing software processes. The software produced meets aspects of reliability, efficiency, integrity and testability. Referring to this, a standard is needed that regulates software quality problems, better known as quality assurance software (QAS). There are several things that make managing application development projects difficult, namely; 1) Not able to define goals and specifications precisely (scope), 2) Lack of good planning, 3) The target time and budget are not appropriate (Samudra, 2006). While the quality of project management depends on the fulfillment of the 3 contrasts that form the basis of the success of project management, namely project management must be able to satisfy the project sponsor in meeting at least three objectives including scope, time and cost which are part of 9 (nine) project management knowledge areas. PMBOK (Project Management Body of Knowledge) in (Project Management Institute, 2004).

In carrying out its application development and implementation projects, APDEV and EESD use project-based management whose organizational structure is adjusted to the project management rules led by a Project Manager (PM) in the PMO division. In order to oversee these activities tools have been developed in the form of the Go Project 
Lean (GPL) application. The GPL application was developed independently by PT. Infomedia Nusantara using the project management concept adopted from the PMBOK. Henceforth, the researcher uses the term Go Project Lean with the term GPL. The GPL application can be allegedly affecting the quality of IT project management which is a source of income that greatly affects management performance, as stated by previous researchers that the use of technology and information systems significantly influences management performance (Hariyanto, 2010). Referring to activities recorded in the GP, application in January 2017 until November 2017 there are 640 projects where 551 projects or $86 \%$ GO status and 89 projects or $14 \%$ return status. Of the 89 or $14 \%$ of the return projects, 60 projects or $9 \%$ are based on IT and the remaining 29 projects or $5 \%$ are non IT. GO status means that the project is approved by the project reviewer, while the return status means that the project must be returned on the grounds that it has not met the terms or conditions of the project policy.

The return process of course requires adjustment time which automatically reduces project development time, which can indicate delays in project implementation and additional costs (Man days) that affect the quality or performance of the project. As stated by previous researchers success or failure of IT implementation in an enterprise is often determined by two things, namely the running of the system configuration and the whole project running on time and still in the budget (Nur Kholish AR, 2011). The delay is seen from the number of projects that delay and are still not finished by passing the time limit. Delays in project completion in the APDEV Division and EESD can have implications for additional resources. Additional resources can have an additional cost in calculating Man days so that it can affect the decrease in profit margin. The business process orientation leads to better and indirect non-financial performance towards better financial performance (Skrinjar, Indihar Stemberger, \& Hernaus, 2017).

Based on the explanation above so the research problem of this study are: 1) How does the business process influence the quality of IT Project Management?, 2) How does the Go Project Lean influence the quality of IT Project Management?, 3) How does the business process and Go Project Lean influence the quality of IT Project Management?. This research aims are: 1) To explain the influence of business processes on the quality of IT Project Management. 2) To explain the influence of the GPL application on the quality of IT project management. 3) To find out the strength and direction of the influence of business processes and applications of GPL on the quality of IT project management.

\section{LITERATURE REVIEW}

Quality can be interpreted as "dynamic conditions related to products, services, human resources, processes, and environments that meet or exceed expectations" and quality in the service industry is a presentation of products or services according to the size prevailing in the place where the product is held and its delivery is at least the same as what consumers want and expect (Tjiptono, 2002). Nusraningrum (2014) mentioned that the dimensions of service quality; namely reliability, responsiveness, guaranteed 
(reassurance), empathy, and tangible. Meanwhile, quality is whatever the needs and desires of consumers (Yamit, 2011). Quality is the degree of some characteristics that meet the requirements, consists of: a). Quality Planing-Identify quality standards for project implementation and how to fulfill them, b). Perform Quality Asurance-Implement a quality assurance plan so that the project meets all requirements, c). Perform Quality Control-Monitor the results of project implementation whether or not meeting quality standards. The quality is all features or characteristics related to products, services, human resources, processes, and environment which are the results of a comparison of expectations and actual performance that is able to meet or exceed consumer expectations which simultaneously and partially influence significant business competition.

The success of a project is also determined by teamwork and careful planning and good management by a project manager. Project management sets and coordinates project objectives and plans and controls resources to achieve project implementation efficiency (Dannyati, 2010). Choosing projects that are right at the beginning and filtering out projects that have the potential to fail, will be more important to ensure the success of the project (Keleckaite \& Meiliene, 2015) added that Non Governmental Organizations (NGOs) that lack sufficient financial and human resources, project management methodologies can help to meet challenges by improving communication among project team members, developing performance, better controlling resources by simplifying project management processes to achieve the most efficient project results.

Project Management is a way to manage complex projects consisting of several activities (Heizer, Jay, Render, 2015). Activities are jobs or tasks that are part of the project time, cost, resources, predecessors and responsible people identified in each activity. Furthermore, (Taylor, n.d.) added that project management is a description of network networks that illustrates a way in which the parts of a project are organized, and they can determine the length of time the project. Project Management is the application of knowledge, skills, tools and techniques in project activities to meet project needs (Rizal, 2013b). Based on the process in Project Management it is divided into 5 parts, namely: a). Initiating process, activities related to the preparation of the implementation of a project, especially concerning the willingness of stakeholders to determine objectives and agree to have full commitment to support the project in terms of the allocation of necessary resources. b). Planning process activities related to planning the implementation of a project, especially in terms of estimating the scope, duration, costs, quality and other parameters that need to be managed in the project. c). Executing process, which is an activity related to coordinating people and resources that are there to run a number of jobs in the project to produce the desired or targeted output. d). Controlling process, activities related to supervision so that all activities carried out in the project consistently lead to the objectives to be achieved. e). Closing process, activity related to formal approval that the project has ended and produced targeted output.

An organization that wants to succeed in managing a project must comply with certain regulations, practices and methodologies (Keleckaite \& Meiliene, 2015). There are 3 constraints which are the basis of the success of a project management, namely 
project management must be able to satisfy the project sponsor in meeting three objectives including scope, time and cost which are part of the 9 projects management knowledge (Rizal, 2013b) consists of; project integration management, project scope management, project time management, project cost management, project quality management, project human resource management, project communications management, project risk management, project procurement management dan project stakeholder management. However, quality of IT project management is the process of planning and controlling resources for managing application development projects that focus on triple constrains, namely scope, time, and cost by comparing project expectations and actual performance.

The business processes can be described by the flow of business activities (Yun, 2011) and is a set of activities to realize business goals starting from input, then adding value to get the output in the form of the desired results (Nur Kholish AR, 2011). Each process is an independent unit that converts input into a similar or different output but can interact with other processes. Business processes as measurable and structured activities to produce certain outputs for certain customers (Davenport, 2013). There is a strong emphasis on "how" the work is carried out in an organization, unlike the focus of a product that focuses on the "what" aspect. A process is therefore a specific sequence of work activities across time and space, with a prefix and suffix, and clearly defines input and output. A chain of activities to produce goods or services from the beginning of the input process, then process until the output is out, and in each activity chain there are additional values called the value chain.

The purpose of analyzing business processes is to analyze and document existing work processes for user satisfaction so that it impacts on organizational performance (Tsai, Wen-Hsien; Chen, Shu-Ping; Hwang, Elliott TY; Hsu, 2010) that user satisfaction and organizational impact are influenced by the relationship between systems and business processes. The process of analyzing existing business processes, must produce a high-level picture to provide a starting point for redesign efforts. The organization analyzes in detail the existing processes, then develops detailed time and cost models, and simulates to study the effects of changes made on improving process efficiency. However, Business Process is the flow of activities to realize business goals starting from the input, then adding value to get output in the form of desired results of consumers, with definitions that are clearly measurable and structured about the beginning of the process, input and output.

An application is developed for the purpose of making it easy for users to be able to access all information and service resources in a safe, consistent and customizable manner. There is a statistically significant influence between the dimensions of the effectiveness of the information system (Quality of the system, quality of information, quality of service) on satisfaction (Pertiwi, 2010). (Rizal, 2013a) found that the application of the project management information system application is able to increase productivity and are greatly influenced by the ease of operation of the system. (Hariyanto, 2010) stated that the use of technology and information systems significantly influences management performance. 
The GPL Application Development Document (Nusantara, 2016a), it is explained that the GPL Application is an IT Project Management application that is used by PT. Infomedia Nusantara as a tool to simplifying and accelerating the IT project management as one of firm's revenue sources. PT. Infomedia Nusantara requires work flow tools that are capable in monitoring, controlling projects, and also able to describe some deviations such as ahead (realization is faster than planned) and delay (realization is slower than planned) (Suanda, 2016). However, although IT capabilities throughout the company present the characteristics of scarcity, mismatch, non-reproducibility, and nonsubstitutability, the impact on organizational performance is fully mediated by the agility of business processes (Chen, Yang; Wang, Yi; Nevo, Saggi; Wang, Luning; Chow, 2014). Project Management applications such as the GPL should be designed for a team. So that it will be very easy for PM to share a job or task with the team. Besides that it must be able to be accessed from multiple devices, so it becomes easier to synchronize anytime and anywhere (Frederik A, 2009).

Cycle 1 - Working Order Process (WO) is the beginning of the GPL application process, where the Sales submit a request for work on the project. The project submitted by the Sales must go through reviews from various sides.

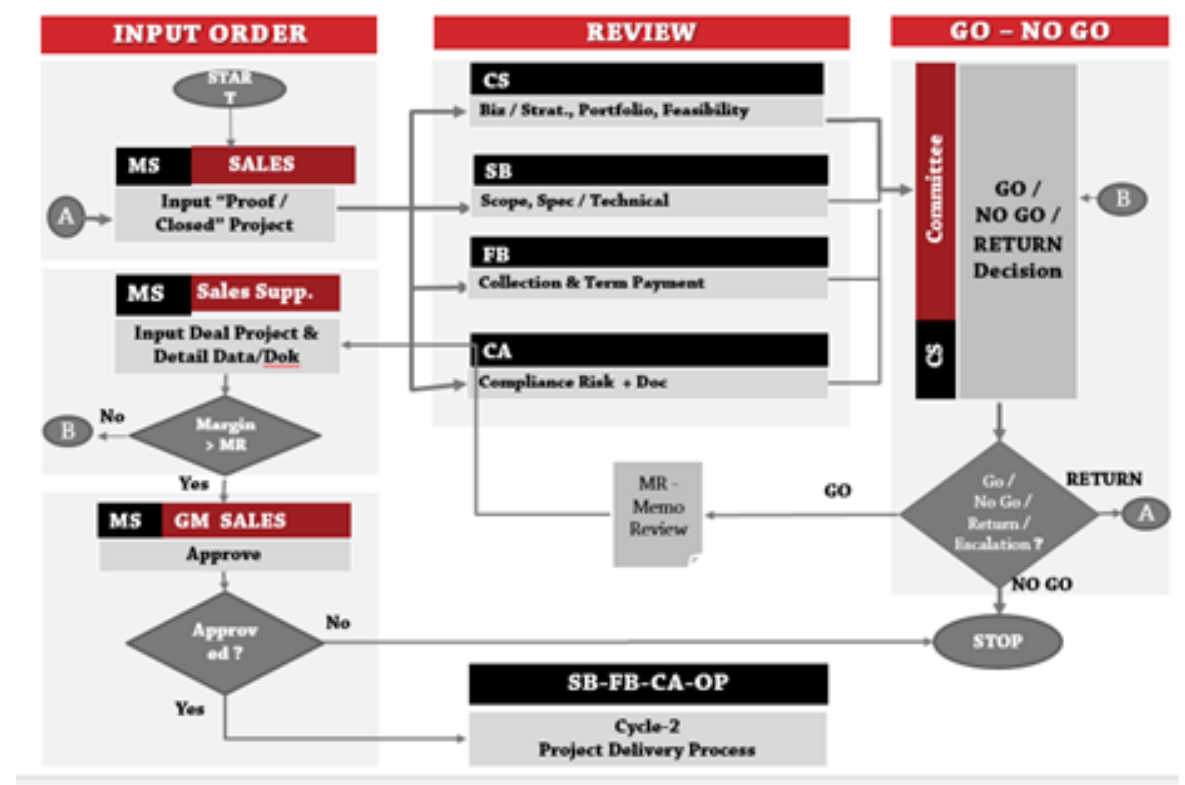

Source: Infomedia Nusantara (2016)

Figure 1. Business process of Cycle 1- Work Order Process

The reviewer can return through the application if the results does not match, and the sales must follow up or complete the results of the project review and then send it back through the application for review until the project is declared feasible. The results of the review will determine whether the project is feasible or not, declared Go or No Go by the head of the project committee. The project committee has a right to declare Go even though other reviewers stated No Go, with consideration of benefits in tangible and 
intangible. The final review results were showed in memo review through the application to be approved by the GM sales. The Go status project then dispatched to the related teams through the application. Each PIC of the project team will be get a notification to follow up the project through the GPL application. Then the process will continue to cycle 2 , namely the delivery process as seen on the Figure 2 .

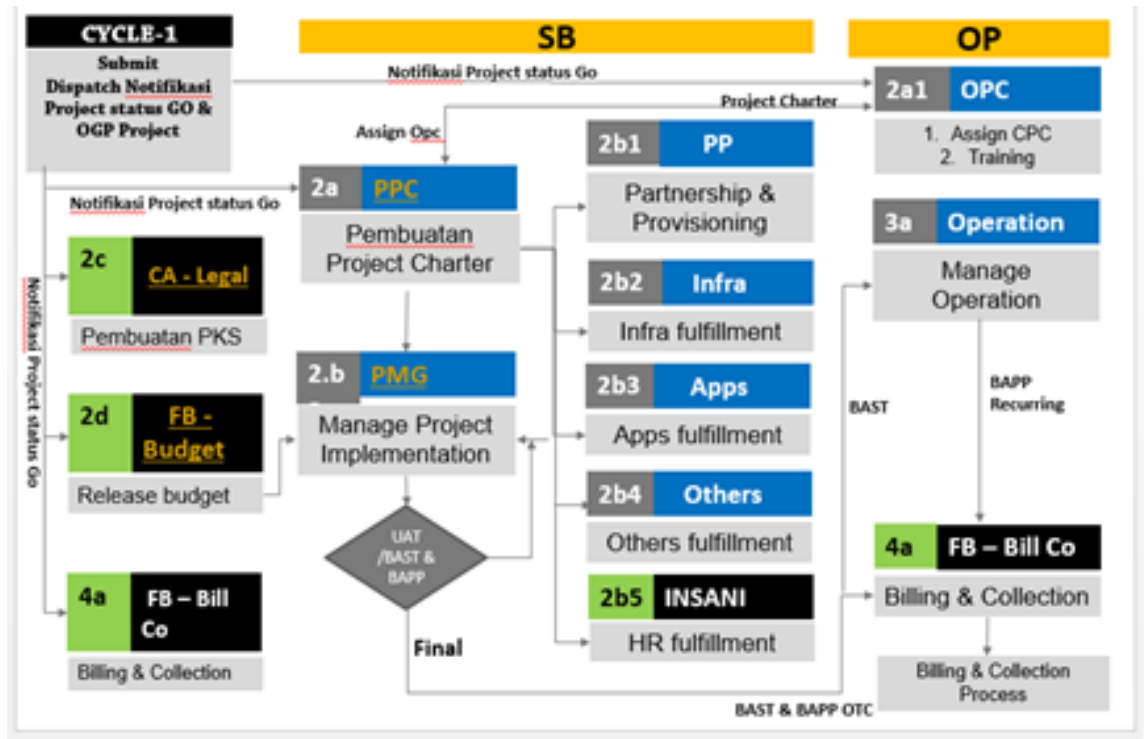

Source: Infomedia Nusantara (2016)

Figure 2. Business process of Cycle 2- Delivery Process

The Cycle 2 begins with notification of the project's Go status. Based on the notification via email, the GPL transaction number Go status can be clicked from an email that will call the GPL application with the transaction number in question. In addition to the Product Planning \& Controlling (PPC) department as the maker of project charter, the Go status notification project is also sent to the legal, budget, operation and billing and collection departments. PPC will then create project charter through the GPL application wherein the project charter contains a summary of the project which includes information on the scope, budget, time, project manager (PM) and the project team which will work on the project. Based on the project charter, the PM will then create a Work Breakdown Structure (WBS) in the form of the following next PIC-PIC and then dispatch it to PICPIC as follow-up according to their respective functions and work. Next the PM will monitor and update the status of the work and periodically revert to each PIC. As a sign that the work meets the customer's standard scope, the PM together with the customer must test together through the User Acceptance Test (UAT) process which is poured into the UAT form signed by both parties. If the PM and the customer accept, the PM will immediately make a Job Handover Report (BAST) to the Customer. Then the process will proceed to cycle 3 , the operation process if the type of project requires operations in the firm, but if the type of project is one-time charge then the process will be followed by the cycle 4 process, the billing and collection process. 
Cycle 3 in Operation Process (OP). Project data flows from cycle 1 and cycle 2. The process starts when operation related to getting a new task notification as a sign that a project is being delivered by PM and is ready to be operational. Handover from PM to operation in the form of a BAST document signed by PM and related operations. Operation related will carry out its functions according to the work contained in the project charter and BAST scope. Furthermore Operation will make the Work Settlement Minutes (BAPP) periodically every month as the basis for billing to the customer. This BAPP must be agreed upon and signed by the relevant operation and customer. Then the BAPP will be forwarded to billing and collection on Cycle 4 to be in the payment collection process.

Cycle 4 - Billing and Collection Process (CO) consists of the revenue recognition process, invoice creation, and payment status. In cycle 4 , the billing and collection will receive a notification that BAST is completed, as a basis for acknowledging revenue project. In addition, BAPP and project supporting data will also be received. Documents flow from the previous cycle so that the document verification process can be done as a basis for making invoices for the collection process. Based on the information, what is meant by GPL Application is an IT Project Management application developed for the purpose of providing convenience to users in order to be able to access all information and service resources in a safe, consistent, and customizable way, complete with work flow, delivery or project management, operation, and the billing and collection process. Based on the literature review so that this study hypothesis is: $\mathrm{H} 1$ : the business process influences the quality of IT project management, H2: The GPL application influence the quality of IT project management, H3: The business process and GPL application influence the quality of IT project management.

\section{RESEARCH METHOD}

This research used quantitative approach with survey to collect the data. Based on its purpose, this research is an explanatory study which aims to explain the causal relationship (influence) and test the hypothesis. The research independent variables: 1). Business process 2). GPL application and the dependent variable is quality of IT project management. The population of this study is the users of GPL application which are the Sales Division, Project Management Office Division, and Application Development Division of PT. Infomedia Nusantara. The sample of this research is 30 respondents. All data from the questionnaires that have been filled by the respondents were analyzed using multiple linear regression technique.

\section{RESULT AND DISCUSSION}

Collected data in this study was analyzed using multiple linear regression technique with SPSS. Multiple linear correlation analysis is used to determine the contribution percentage of the influence of the independent variable business process $\left(\mathrm{X}_{1}\right)$ and GPL application $\left(\mathrm{X}_{2}\right)$ on the dependent variable quality of IT project management $(\mathrm{Y})$. This coefficient shows how much the percentage of independent variables used in the model 
is able to explain the dependent variables. If $\mathrm{R}^{2}$ is equal to zero, then there is not the slightest percentage of the influence that is given by the independent variable on the dependent variable or the independent variables used in the model does not explain the least dependent variables and vice versa.

Table 1. Adjusted R coefficient

\begin{tabular}{llcc}
\hline $\mathrm{R}$ & $\mathrm{R}^{2}$ & Adjusted $\mathrm{R}^{2}$ & Std. Error \\
\hline 0.756 & 0.771 & 0.540 & 3.029 \\
\hline
\end{tabular}

Table 1. show that the determination coefficient or $\mathrm{R}$ Square $\left(\mathrm{R}^{2}\right)$ are 0.771 or $77.1 \%$. This shows that the percentage of the influence of the independent variable (business process, GPL application) on the dependent variable quality of IT project management (Y) is $77.1 \%$ while the remaining $22.9 \%$ is influenced by other variables not included in this study. The value of $R$ which is positive and has a value of 0.756 can be interpreted that there is a relationship and a positive influence between the quality of IT project management and the business process and application of GPL. So the multiple linear regression equation is:

$$
\mathrm{Y}=2.348+(0.059) \mathrm{X} 1+(0.402) \mathrm{X} 2
$$

Constant value quality of IT project management (a) $=2,348$ means that, if the business process variable, the GPL application is considered constant, then the uality of IT project management is 2,348. The GPL application coefficient value is positive. Business process ariables on the quality of IT project management with a regression coefficient of 0.059 means that, whenever there is an increase in business process (work order and delivery process) then the quality of IT project management (on time delivery project, on budget delivery project, on scope delivery project) will increase by 0.059 , and vice versa. The value of the business process coefficient is positive. GPL application variable on the quality of IT project management with a regression coefficient of 0.402 means that, whenever there is an increase in the GPL Application (service system quality \& application information quality, users satisfaction on GPL application, function of project management and function of collaboration) then the quality of IT project management (on time delivery project, on budget delivery project, on scope delivery project) will increase by 0.402 and vice versa with the assumption that the independent variable/other free values are fixed. the business process, and GPL Application simultaneously have a significant effect on the quality of IT project management

Table 2. Simultaneous Test Results (Test F)

\begin{tabular}{|c|c|c|c|c|c|c|}
\hline \multicolumn{2}{|c|}{ Model } & Sum of Squares & df & Mean Square & $\mathrm{F}$ & Sig. \\
\hline 1 & Regression & 330.133 & 2 & 165.066 & 43.990 & 0.000 \\
\hline & Residual & 247.734 & 27 & 9.175 & & \\
\hline & Total & 577.867 & 29 & & & \\
\hline
\end{tabular}


Table 2 in column F, the F value of 43.990 in the Sig column is the probability value or significant at 0.000 or $0 \%$ significance. The $F$ table value for the significance level $(\alpha)$ $=5 \%$ two tailed is 3.35. The above analysis is $43.990>3.35$ then $\mathrm{H} 0$ is rejected means significant. Based on the probability: if $<0.05$ then Ho is rejected, the results of the analysis are obtained $\mathrm{Sig} 0,000<0,05$ means that $\mathrm{Ho}$ is rejected and $\mathrm{Ha}$ is accepted. Thus, it can be concluded that business process and GPL application simultaneously have a significant effect on the quality of IT project management.

Table 3. Hypothesis test results ( $t$ test)

\begin{tabular}{cccccccc}
\hline & & \multicolumn{2}{c}{ Unstandardized Coefficients } & \multicolumn{2}{c}{ Standardized Coefficients } & & \\
\cline { 2 - 5 } & Model & $\mathrm{B}$ & Std. Error & Beta & & Sig. \\
\hline 1 & (Constant) & 2.348 & 9.172 & & 0.038 & 0.970 \\
& $\mathrm{X}_{2}$ & 0.402 & 0.067 & 0.755 & 5.984 & 0.000 \\
& $\mathrm{X}_{1}$ & 0.059 & 0.079 & 00.095 & & 3.754 & 0.000 \\
\hline
\end{tabular}

Table 3 shows the result of the hypothesis testing ( $t$ Test) that $F$ table is 1.70329 can be seen from the business process variable the value of $t$ value $3.754>t$ table 1.70329 and the significance level of $0.000<0.05$ so hypothesis 1 is accepted, business process variables can be significantly positive affected quality of IT project management. And from the Table 3 also seen that hypothesis 2 is accepted. GPL application variable has the $\mathrm{t}$ value is $5.984>\mathrm{t}$ table 1.70329 and the significance level is $0,000<0.05$. The GPL Application variable has a significant positive effect to the quality of IT project management. Table 5 show the result of the inter-dimensional correlation analysis that determine the which dimensions of the independent variable that have stronger effect to the dependent variables.

Table 5. Interdimensional Dimension Research Correlation Matrix

\begin{tabular}{lccc}
\multicolumn{1}{c}{ Variable / Dimension } & $\begin{array}{c}\text { On Time } \\
\text { Delivery Project }\end{array}$ & $\begin{array}{c}\text { On Budget } \\
\text { Delivery Project }\end{array}$ & $\begin{array}{c}\text { On Scope } \\
\text { Delivery Project }\end{array}$ \\
\hline Business Process & & & 0.712 \\
Work Order (WO) & 0.714 & 0.640 & 0.608 \\
Delivery Process (PM) & 0.763 & 0.679 & 0.686 \\
GPL Application & & & \\
Service System Quality \& Application & 0.696 & 0.624 & 0.364 \\
Information Quality (GPL) & & & 0.539 \\
Users Satisfaction on GPL application & 0.402 & 0.477 & 0.456 \\
Function of Project Management & 0.576 & 0.562 & 0.577 \\
Function of Collaboration & 0.575 & & \\
\hline
\end{tabular}

From the Table 5 we can see that the correlation of business processes to the quality of IT project management has the strongest dimension with a strong relationship level are indicated by the dimensions of the delivery process (PM) with an on time delivery project dimension of 0.763 . Whereas the lowest level of relationship is indicated by the delivery 
process dimension (PM) with a dimension on scope delivery project of 0.608 . Correlation of GPL applications to quality of IT project management has the strongest correlation dimensions with a strong relationship level indicated by the dimensions of service system quality \& application information quality with an on time delivery project of 0.696. And the lowest is the dimension of GPL application user satisfaction with an on scope delivery project of 0.364 .

The business process significantly influences the quality of IT project management. The "work order" business process is very necessary because it is related to the completeness, measurability, structure and effectiveness of project management. completeness, measurability, structure and effectiveness of project management will have an impact on improving the quality of projects that are delivered on time, on budget, and on scope. Vice versa, incomplete, unmeasured and structured, and the ineffectiveness of project management will also have an impact on decreasing the quality of the project. This research supports the previous research of Nurcholis (2011) which stated that with business processes which are a set of activities to realize business goals starting from input, then adding value to get the output in the form of desired results, with definitions that are clearly measurable and structured about the beginning of the process, end of process, input and output. A set of activity chains to produce goods or services from the beginning of the input process, then process to exit the output, and in each activity chain there are additional values called the value chain.

The quality of IT project management is also significantly affected by the delivery project business process or project management business process, if the project workflow process is structured according to established process procedures, and the project can be measured in time, budget, and scope with predetermined documents contained in the project charter document generated by the previous cycle, namely "work order", the project will be delivered on time, on budget, and on scope in other words the quality of IT project management will be maintained. Based on the results of the research, what was felt to be the most difficult was how a PM maintains a Scope that has been agreed with the customer through an agreement document. However, in the field even though an agreement document has been made, sometimes there is still a mandatory scope change request that must be fulfilled and affects the quality of on time and on budget delivery.

The agreement document which is the core document must still exist because it becomes the basis of the delivery project. This research supports previous research as research conducted by (Prasetio, 2006) found a comparative ability of E-Proman which is an electronic project management application with other project management software that is often used in managing projects. The E-Proman business process significantly influences the quality of IT project management especially the business aspects of project management processes, which include processes and activities that are specific in nature to carry out continuous and consistent evaluations of the project. Examples of processes included in this aspect are: task management, scheduling, reporting, document management, budgeting, scoping projects, milestones and risk / benefit analysis.

The GPL application has a significant effect on the quality of IT Project 
Management. That is, if GPL application is able to provide quality service system \& application information quality in terms of consistency, availability, functionality, accuracy $\&$ reassurance, reliability, complete, tangible, responsiveness, time response and meet user satisfaction, being able to project management tools, and means of collaboration teams such as room chat, are very influential on on time delivery, on budget delivery and on scope delivery so that it significantly improves the quality of IT project management.This study supports previous research as stated by previous researchers that use of technology and information systems significantly influences management performance (Hariyanto, 2010).

\section{CONCLUSION}

Business process influences PT Infomedia Nusantara's quality of IT project management positively and significantly. The dimensions of the most powerful business process variable are the delivery process (PM). Where IT project management of PT. Infomedia Nusantara will be of higher quality if supported by business processes that are complete, effective, measurable, structured, and defined from input to output. The GPL application influences PT Infomedia Nusantara's Quality of IT project management positively and significantly. The most powerful dimension of the GPL application variable is the ability of the GPL application, where the IT Project management of PT. Infomedia Nusantara will be of higher quality if supported by the GPL application that is capable of providing quality services and information, capable of providing user satisfaction and information, and being able to function as project management tools and provide collaboration functions.

Business processes and GPL applications affect PT Infomedia Nusantara's quality IT project management positively and significantly. The dimensions of the most powerful business process variables are the delivery process (PM) and the dimensions of the most powerful GPL application variable that are related to the ability of the GPL application. Where IT project management PT. Infomedia Nusantara will be of higher quality if supported by business processes that are complete, effective, measurable, structured, and defined from input to output, and supported by the GPL Application Capabilities used by sales, PMO, and application development. who are able to provide quality services and information, are able to provide user satisfaction and information, and are able to function as project management tools and provide collaboration functions.

\section{REFERENCES}

Chen, Yang; Wang, Yi; Nevo, Saggi; Wang, Luning; Chow, W. S. (2014). IT capability and organizational performance: the roles of business process agility and environmental factors. European Journal of Information Systems, 23(3).

Dannyati, E. (2010). Optimalisasi Pelaksanaan Proyek Dengan Metode Pert dan CPM (Studi Kasus Twin Tower Building Pasca Sarjana UNDIP). Universitas Diponegoro.

Davenport. (2013). Process Innovation: Reengineering Work Through Information 
Technology.

Frederik A. (2009). Towards a Conceptual Reference Model for Project Management Information System. Journal of Project Management, 23(1), 19-30.

Hariyanto, A. (2010). Pengaruh Penggunaan Teknologi Informasi, Sistem Manajemen

Mutu Dan Budaya Organisasi Terhadap Kinerja Manajemen Akademi Sekretari

Dan Manajemen Don Bosco. Universitas Guna Darma.

Heizer, Jay; Render, B. (2015). Operations Management (ManajemenOperasi) (11th ed.). Jakarta: Salemba 4.

Keleckaite, M., \& Meiliene, A. E. (2015). Case Study of Lithuania and Germany The Importance of Project Management Methodologies and Tools in NonGovernmental Organizations: Case Study of Lithuania and Germany. PM World Journal, IV(VII), 1-17. Retrieved from www.pmworldlibrary.net

Noor II, A. R. (2015). Geliat Cloud di Indonesia: Bisnis Cerah yang Diselimuti Awan Gelap Regulasi. Retrieved October 1, 2017, from http://inet.detik.com/read/2015/10/08/110442/3039196/319/geliat-clouddiindonesia-\%0Abisnis-cerah-yang-diselimuti-awan-gelap-regulasi

Nur Kholish AR, M. (2011). Manajemen Proses Bisnis: Faktor Sukses Implementasi Teknologi Informasi di Organisasi Bisnis. Jurnal Manajemen Proses Bisnis.

Nusantara, P. I. (2016a). Go Project Lean. Retrieved April 16, 2017, from http://gpl.infomedia.co.id/

Nusraningrum, D. (2014). Pengembangan Instrumen Antecedent Gap ServQual Antecedent Gap ServQual Instrument Development. 01(01), 43-50.

Pertiwi, P. T. (2010). Analisis Faktor-Faktor Yang Mempengaruhi Keefektifan Implementasi Sistem Informasi Pada Portal Akademik FE UGM. Universitas Gadjah Mada.

Prasetio, S. (2006). TELKOMRDC Software Quality Assurance. TELKOMRDC.

Project Management Institute. (2004). A Guide to the Project Management Body of Knowledge - PMBOK Guide. In Project Management Journal (Vol. 44). https://doi.org/10.1002/pmj.21345

Rizal, A. (2013a). Analisis Penerapan Project Management Information System (PMIS) Menggunakan Metode Technology Acceptance Model (TAM) Studi Kasus PT. INDOSAT, Tbk. Jurnal Telekomunikasi Dan Komputer, 5(1), 1-24.

Rizal, A. (2013b). Analisis Penerapan Project Management Information System (PMIS) Menggunakan Metode Technology Acceptance Model (TAM) Studi Kasus PT. INDOSAT. Jurnal Telekomunikasi Dan Komputer, 5(1), 1-24.

Samudra, P. (2006). Evaluasi Dan Pengembangan Electronic Project Management (EPROM) Di TELKOM (Research \& Development Center). Universitas Gadjah Mada.

Skrinjar, R., Indihar Stemberger, M., \& Hernaus, T. (2017). The Impact of Business Process Orientation on Organizational Performance. Proceedings of the 2007 InSITE Conference, (June 2018). https://doi.org/10.28945/3150

Suanda, B. (2016). Advanced \& Effective Project Management (1 st ed.). Jakarta. 
Sugiyono. (2014). Metode Penelitian Bisnis : Pendekatan Kuantitatif, Kualitatif, dan $R \& D$ (18th ed.). Bandung: Alfabeta.

SWA. (2016, August). No Title. Retrieved from http://swa.co.id/

Taylor, J. (n.d.). The History of Project Management: Frederick Taylor and 19th Century Business Ideas. Retrieved November 1, 2017, from https://www.brighthubpm.com/monitoring-projects/11643-pm-history-fredericktaylor-and-19th-century-peak-performance/

Tjiptono, F. (2002). Manajemen Jasa. Jogyakarta: Andi Offset.

Tsai, Wen-Hsien; Chen, Shu-Ping; Hwang, Elliott TY; Hsu, J.-L. (2010). A Study of the Impact of Business Process on the ERP System Effectiveness, International Journal of Business and Management. International Journal of Business and Management, 5(9), 26-37.

Yamit, Z. (2011). Manajemen Kualitas Produk dan Jasa (4th ed.). Jogyakarta: Ekonisia.

Yun, C. B. (2011). Business Process Management of Telecommunication Companies: Fulfillment and Operations Support and Readiness Cases. Journal of Future Generation Communication and Networking, 4(3), 1-14. 